\title{
Regulation of Pension Fund Credit Risk: Lessons from the Banking Sector
}

\author{
Pedro Americo Herbst * \\ Faculdades IBMEC-RJ
}

\author{
Antonio Marcos Duarte Júnior* \\ Faculdades IBMEC-RJ
}

\begin{abstract}
This article examines the regulatory framework for managing the credit risk of pension funds in Brazil. We believe that the current framework is not very effective at controlling credit risk, and also overly limits the investment possibilities of pension fund managers. We consider the regulatory framework for banks as an alternative approach for future developments, and propose that the rules on credit risk exposure of pension funds and banks be made uniform. The resulting regulatory framework would be more effective and easy to monitor, facilitating the work of external supervision and auditing. Finally, we present a numerical example using real data on six Brazilian pension funds to illustrate the proposal.
\end{abstract}

Keywords: pension funds, regulatory framework, credit risk

Received in 04/12/2007; revised in 05/26/2007; accept in 06/03/2007.

Corresponding authors:

* Rua das Laranjeiras, 210

Laranjeiras Rio de Janeiro- $R J$ - Brazil

** Av. Pres. Wilson, 118, 9 andar

CEP 22240-001 - Tel.: 2122055113

Centro, Rio de Janeiro - RJ - Brazil

pedro.ah@globo.com

CEP 20030-020 - Tel.: 2145034060

Faculdade de Economia e Finanças do IBMEC-RJ

aduarte@ibmecrj.br

Faculdades Ibmec / RJ

Editor's note: This paper was accepted by Alexsandro Broedel Lopes. 


\section{INTRODUCTION}

$\mathrm{P}$

ension funds are extremely important as vehicles for forming internal savings. Their assets represent roughly 18\% of Brazil's GDP according to the Brazilian Association of Private Closed Pension Entities (ABRAPP (2006)). They are also important sources of financing to foster the country's economic development. However, the main concern in managing the resources of pension funds must always be payment of benefits to the participants and other beneficiaries. Investments made without adequate consideration of risks (particularly credit and market risks), along with highly restrictive supervision, have recently led to huge financial losses and harm to the image of pension funds. Two examples stand out:

In November 2004, some pension funds held investments in bank certificates of deposit in Banco Santos. When this bank was liquidated, these assets were marked as losses for the investors.

In April 2006, the Secretariat of Complementary Social Security (SPC) decreed intervention in Instituto Aerus de Seguridade Social (manager of the employee pension fund of Varig, RioSul, Varig Log and Transbrasil). The sponsoring companies of the distressed Varig Group had failed to pay in approximately $\mathrm{R} \$ 2.3$ billion to the pension fund over a number of years. In the whole, there were over twenty negotiations of debt between Aerus and Varig. This and other factors such as the ending of the third source of the plan's financing (3\% on domestic air tickets) are being target of juridical questioning from part of the participants, in which they try to show that the state should be held responsible for the event.

According to Costa e Silva (2006) it is difficult to know the right moment to act in such cases. However, it always helps to have benchmark concerning international practices there are measures which SPC could adopt beforehand. For example, the SPC could determine a minimum acceptable level of patrimony to cover the commitments of the plans. Say, in plans in which the patrimony represented less than $70 \%$ or $80 \%$ of the commitments, the sponsors and participants would be forced to increase contributions. In addition to that, these plans wouldn't be allowed to improve benefits, and finally, would be liquidated when the guarantee of commitments was inferior to a given level within a given time range. Pension funds are similar to banks as far as institutional image is concerned. In both sectors, the biggest enemy is systemic risk.

The legislation on management of pension fund assets and liabilities must therefore be rigorous enough to guarantee preservation of the rights of the beneficiaries, but without being so restrictive as to preclude investments that can obtain the returns necessary to pay benefits to these beneficiaries (Blake (1997, 2000), Chutcuti (2006), Davis (2001), OECD (2006a, 2006b)). In other words, the regulatory entities must try to avoid compulsory and restrictive measures that do not give margin for pension fund managers to do their job, taking into consideration the specificities of the assets held, such as requirements for adequate return, risk exposure and the need for liquidity, in line with the recommendations of Ziemba and Mulvey (1998).

Effective regulation should be based on supervising and monitoring the risks to which pension funds are exposed (Word Bank (2006)). Supervisors should accompany, evaluate and stipulate mechanisms for risk management instead of setting limits for investments.

Brazilian pension funds in recent years have been keeping nearly two-thirds of their assets invested in fixed-income papers (ABRAPP (2006)), mostly federal government bonds. If we disregard Previ (Caixa de Previdência dos Funcionários do Banco do Brasil), the 
nation's largest pension fund, the amount held in fixed-income investments totals over $75 \%$ of assets.

However, a paradigm shift and the significant improvement in Brazil's economic fundamentals, combined with a benign external scenario, are causing the expected real interest rate on these investments to fall, in the short, medium and long term. Faced with these expectations, various pension funds have been changing their investment strategies by increasing their investments in long-term bonds issued by the private sector. This movement seeks to optimize profitability to satisfy long-term actuarial targets. However, this change is being hindered by an existing body of legislation that is in drastic need of updating to fit the new reality. In this respect, there is a growing need for good credit risk management by pension funds.

In this article we consider the existing legislation covering the segment in Brazil and compare it with that on the banking sector. Then we present some possible regulatory advances to facilitate pension funds' adoption of the best practices of the banking sector for managing credit risks.

In the next section we review the current regulatory framework for pension funds in Brazil. In the third section, we present some practical examples as a way to illustrate the existing fragility of Brazilian regulation on credit risk management by pension funds. In the fourth, we examine the main advances in credit risk management in the banking sector, to base possible improvements in the regulation of pension funds. The fifth section contains a proposal for regulatory change, along with a practical analysis of some Brazilian pension funds, and the sixth section concludes.

\section{THE REGULATORY FRAMEWORK FOR BRAZILIAN PENSIONFUNDS}

The fiscal restrictions of the Brazilian public sector in the 1980s and 90s resulted in an increased need to find private financing sources. Faced with this fact, a change in the role of the private sector and pension funds became crucial as a wayto finance the public debt. ${ }^{1}$

At the end of the 1990s, because of the privatization process and the need for investments, there was a significant demand for alterations in the regulatory environment regarding risk management of banks, insurers and pension funds (Duarte and Lélis (2004), Garcia (2003), among others).

From the end of 1996 until April 2000 the rules on the investments of pension funds was $\mathrm{CMN}^{2}$ Resolution 2324/96 ${ }^{3}$. This resolution provided general rules on the investment of resources, diversification and maximum allowable percentages. It was replaced by CMN Resolution 2720/00, which permitted making substantially different types of investments than traditional ones (such as debentures issued by special purpose companies, to finance projects).

CMN Resolution 2720/00 was revoked by CMN Resolution 2829/01, even before the grace period given for pension funds to adjust their portfolios to its requirements. The new resolution sought to encourage the adoption of best corporate governance practices, besides stimulating professional management of assets. It considerably reduced the difficulties for satisfactory classification of assets compared with CMN Resolution 2720/00.

\footnotetext{
${ }^{1}$ It should be pointed out that most of the largest pension funds in Brazil cannot be classified strictly as private, in that they are sponsored by government controlled companies, such as Banco do Brasil (Previ), Petrobras (Petros) and Caixa Econômica Federal(Funcef).

${ }^{2}$ Conselho Monetário Nacional: National Monetary Council.

${ }^{3}$ The numbers after the slash mark indicate the year of issuance.
} 
CMN Resolution 3121/03 substituted CMN Resolution 2829/01. It maintained the principal guidelines established by Resolution 2829/01, with some modifications regarding the new attributes of the oversight board (conselho fiscal), monitoring the results of investments and compliance with the investment policy.

CMN Resolution 3121/03, currently in force, establishes limits by segment, subsegment and type of asset, besides imposing numerous restrictions and prohibitions. It determines that resources be allocated in four overall segments, and then in various subsegments, subject to the limits shown in Figure 1.

Figure 1. Limits Established by CMN Resolution 3.121/03

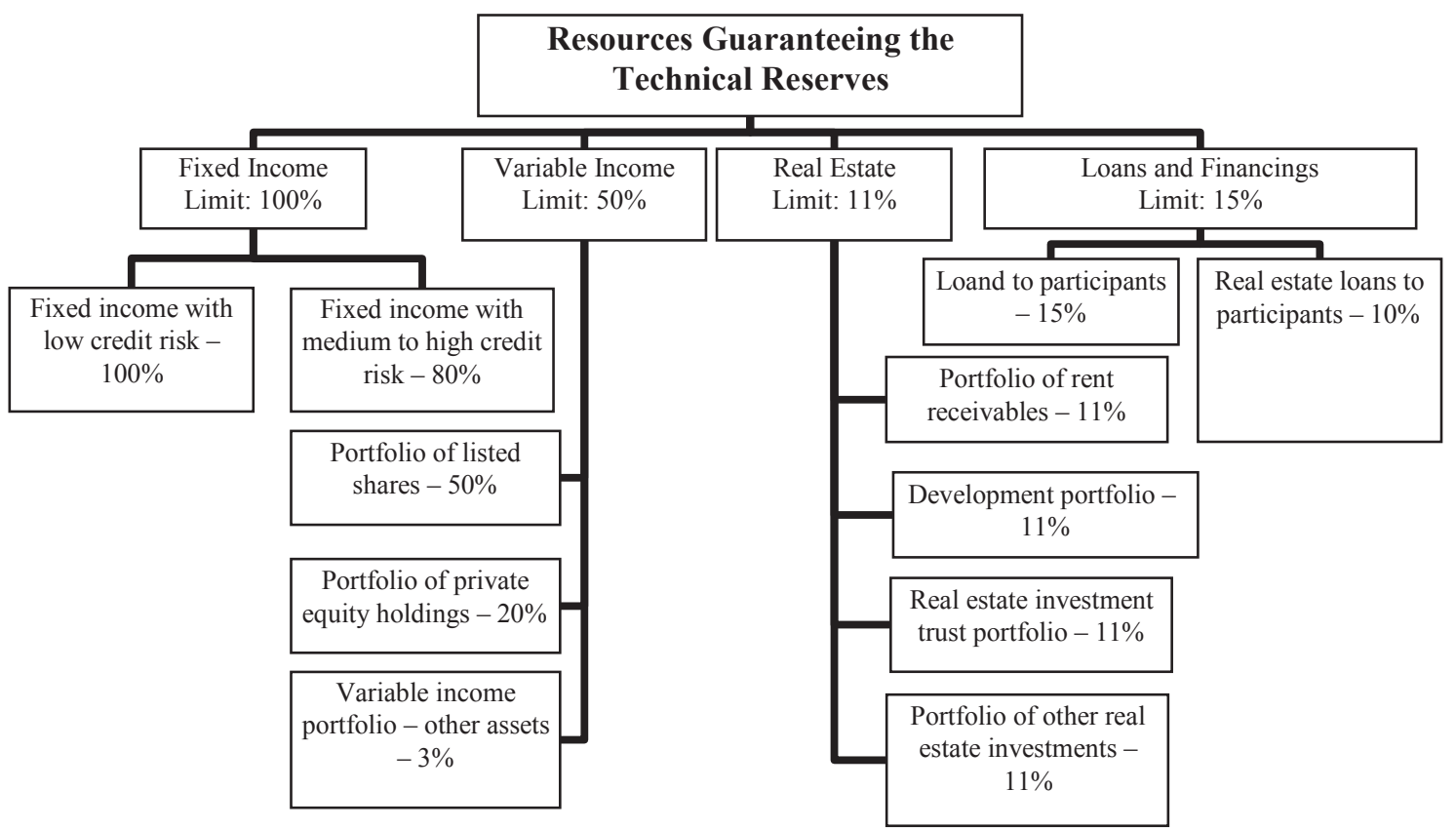

So, although it continues to be highly restrictive, the regulatory climate has undergone significant changes in the past decade. Among them are the possibility of investments in infrastructure projects, closely held companies and real estate receivables certificates.

The main objective of the current pension fund investment regulations is to impose, through various restrictions, an effective diversification of funds' portfolios and to reduce credit, market and liquidity risks. But this form of restricting pension funds' investments is ineffective for various reasons, as discussed in Duarte (2005).

In countries where the basic interest rate is higher than the actuarial targets of pension funds (as is the case for Brazil), the need for higher yielding assets is not, in principle, of extreme relevance for a defined-benefit plan. However, for a defined contribution plan this can be a factor that will result in variations in the participants' benefits (Choi, Laibson, Madrian and Metrick (2001)).

The regulations in various OECD countries do not impose restrictions on pension fund investments. The regulations in these countries follow the "prudent man" rule. On the other hand, countries such as Germany and Denmark, and practically all Latin American countries, impose numerous restrictions. The regulations of these countries are said to be "quantitative". Some differences among the restrictions of five developed countries are shown in Table 1 (according to information in OECD (2006b)). 
The restrictions placed on German and Danish pension funds are less stringent than those on Brazilian funds (as shown in Figure 1 and Table 1). Nevertheless, the same discontent expressed by Brazilian pension fund managers is also present in Germany and Denmark.

Table 1. Main Restrictions on Pension Funds in Five Developed Countries

\begin{tabular}{|c|c|c|c|c|c|}
\hline & Germany & Denmark & USA & Ireland & England \\
\hline Shares & $30 \%$ (listed) & $40 \%$ & No limit & No limit & No limit \\
\hline Real Estate & $25 \%$ & $\begin{array}{l}40 \% \text { together } \\
\text { with investment } \\
\text { funds }\end{array}$ & No limit & No limit & No limit \\
\hline Corporate Bonds & $50 \%$ & No limit & No limit & No limit & No limit \\
\hline Investment Funds & $30 \%$ & $\begin{array}{c}40 \% \text { together } \\
\text { with real estate }\end{array}$ & No limit & No limit & No limit \\
\hline Loans & $50 \%$ & No limit & No limit & No limit & $\begin{array}{c}\text { No loans } \\
\text { allowed }\end{array}$ \\
\hline Bank Deposits & $50 \%$ & No limit & No limit & No limit & No limit \\
\hline $\begin{array}{l}\text { Minimum Required } \\
\text { Diversification }\end{array}$ & $\begin{array}{l}\text { Maximum of } 5 \% \text { per } \\
\text { issuer, except for issues } \\
\text { by the states, bank } \\
\text { deposits and mortgages, } \\
\text { where the limit is } 30 \% \\
\text { per issuer. }\end{array}$ & No limit & No limit & $\begin{array}{l}\text { Maximum } \\
\text { of } 10 \% \text { for } \\
\text { a single } \\
\text { issuer }\end{array}$ & No limit \\
\hline $\begin{array}{l}\text { Limits on Foreign } \\
\text { Investments }\end{array}$ & $\begin{array}{l}\text { Limits: } 30 \% \text { for shares } \\
\text { of companies in the Euro } \\
\text { Zone; } 25 \% \text { in private } \\
\text { equity stakes in the Euro } \\
\text { Zone; } 6 \% \text { shares outside } \\
\text { the Euro Zone; and } 5 \% \\
\text { in bonds outside the } \\
\text { Euro Zone. }\end{array}$ & Limited to $20 \%$ & No limit & None & No limit \\
\hline
\end{tabular}

In comparative studies, some authors have found that in countries where pension fund managers have greater freedom to allocate resources in their portfolios the returns obtained are on average up to twice those in countries where there are stringent restrictions, as shown in Table 2 (according to data from Chutcuti (2006)).

Hence, there is reason for concern over the current regulatory framework of pension funds in Brazil, because it does not make any real and proven contribution to the security of the investments, while imposing difficulties in managing the assets and liabilities. In short, quantitative regulation is open to criticism.

Table 2. Real Return in Local Currency (1984-1998)

\begin{tabular}{l|l|l|r}
\hline \multicolumn{2}{l|}{ “Prudent Man" Regulation } & "Quantitative” Regulation & $7 \%$ \\
\hline Ireland & $13 \%$ & Germany & $6 \%$ \\
\hline United States & $11 \%$ & Denmark & $5 \%$ \\
\hline England & $10 \%$ & Switzerland & \\
\hline & & & $\mathbf{6 . 0 \%}$ \\
\hline Average & $\mathbf{1 1 . 3 \%}$ & Average & \\
\hline
\end{tabular}


Markowitz studied the problem of optimal selection of assets for investment portfolios. Two of his contributions were: (1) showing that a portfolio's risk is not simply the sum of the risks of the assets composing it; and (2) proposing a method for structuring optimal portfolios (Elton, Gruber, Brown and Goetzmann (2004)). Using statistical concepts, Markowitz calculated the return and risk of portfolios and then traced out a region called the efficient frontier. Starting from the premise of a rational investor, for a given level of expected return an investor will choose the portfolio with the lowest possible risk, and for a given level of risk, the investor will choose the portfolio with the highest expected return. The set of points that for each level or risk is associated with the maximum return, or for a given level of return is associated with the minimum risk, forms the efficient frontier.

In conditions of full freedom to invest resources, the participation of some assets can be significant, or in other cases not even exist. In a segment of the economy where regulation is highly restrictive, the investment opportunities diminish, which makes the efficient frontier shift to the right and downward. Under these conditions, by definition the portfolios situated below the unregulated efficient frontier are inefficient, in the sense that for a given level of return there exists a portfolio with better return. Figure 2 illustrates this, with AA representing the efficient frontier without restrictions and BB the efficient frontier with restrictions.

Figure 2. Efficient Frontiers for Different Levels of Restrictions

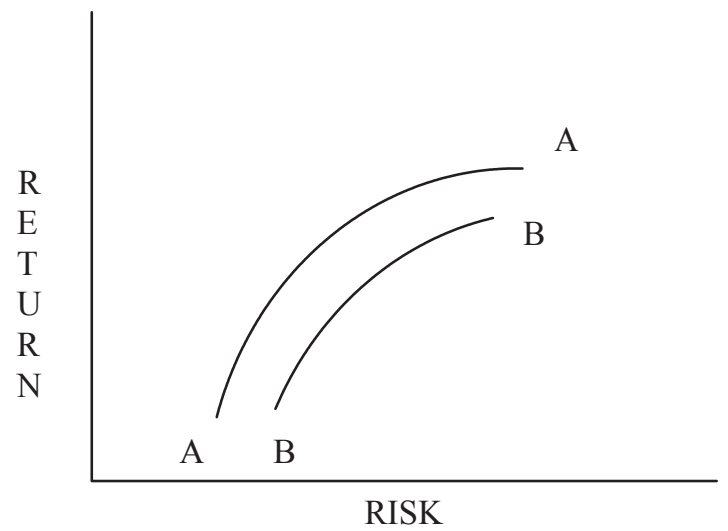

In a study by Contador and Costa (1998), which examined the legislation affecting Brazilian pension funds, the authors found that besides the existence of an inefficiency cost because of current regulation, there was a cost because of inefficient management. In relative terms, the annual loss because of inefficient management of pension funds is $0.88 \%$, against $1.11 \%$ because of regulation. In this sense, one can conclude that the cost of regulation is well above the cost of inefficient portfolio management.

As a consequence, the sponsoring companies and participants in a country with a high degree of regulation receive a much lower rate of return than those in a country with more liberal regulation. Typically, the strict limitations result in greater administrative costs and lower benefits, lowering the attractiveness for employees and employers to finance pension funds. Forced diversification because of regulatory demands can even unnecessarily increase risk (Duarte (2005)). 


\section{PROBLEMS IN THE RESTRICTIONS OF CMN RESOLUTION 3121/03}

Besides the points raised above, which are common to all countries with quantitative regulation, the regulatory framework in Brazil generates a series of other distortions resulting from its peculiarities.

We can cite as a first example a company that wants to issue debt, assigning credit rights (receivables) to guarantee the operation. It can structure this operation in at least three ways: (1) issue a bank credit note ${ }^{4}$ (cédula de crédito bancário, or CCB), (2) issue simple debentures not convertible into shares but secured by the receivables; or (3) set up a receivables investment fund (RIF) to issue securities, with right of recourse by the holders of the credit rights 5 .

Assuming the operation is correctly structured, the maximum volume a pension fund can participate in the operation is related to the restrictions of CMN Resolution 3121/03, shown in Table 3.

Table 3 - Maximum Participation According to CMN Resolution 3121/03

\begin{tabular}{l|c|c}
\hline Asset & Segment & Limit on Issue / Series \\
\hline RIF Securities & Fixed Income & $25 \%$ \\
\hline Debentures & Fixed Income & $25 \%$ \\
\hline CCB & Fixed Income & $100 \%$ \\
\hline
\end{tabular}

Besides the differences described above, RIFs are subject to an added limitation: the above resolution establishes that the set of investments made in RIFs must be limited to $10 \%$ of the pension fund's resources, in RIFs deemed to have low credit risk, and $5 \%$ in RIFs considered to have medium/high credit risk.

In the example above, the credit risk is essentially the same for all three alternatives, with the only difference being the means chosen to structure the operation. To establish different limits for operations with the same underlying credit risk can generate distortions in terms of rate and amounts in the financial market, principally when considering a segment involving the amount of money as that invested by pension funds.

As a second example, we can suppose that a determined pension fund wants to invest in a RIF. CMN Resolution 3121/03 establishes that these vehicles must be classified in the fixed-income segment, However, RIFs can also be used for other types of operations.

A RIF can be used to structure a securitization of debentures of closely held companies that can be convertible into shares, with participation in profits; it can also give the RIF administrator the right to elect members of the issuing company's board of directors and the power to veto investments, among other possibilities.

An investment structured as above, but through a private equity investment fund instead of a RIF, is classified by CMN Resolution 3121/03 as being in the variable-income segment. On the other hand, if the same investment can be made in the fixed-income segment by structuring it through a RIF. Hence, there is an opportunity for regulatory arbitrage, which is not good in practice for the market.

The two examples presented are related to a greater problem, which is that trying to mitigate risks (credit, market, liquidity risks, for example) by restricting the classes of assets and/or instruments available for investment is not very efficient, and can often bring high costs in terms of reduced yield on investments.

\footnotetext{
${ }^{4} \mathrm{~A} \mathrm{CCB}$ is a credit instrument specific to Brazil, issued by the borrower in favor of the bank, that increases the speed with which a loan claim can be enforced.
} 
Since there is room for substantial evolution in the regulation of credit risks in the case of pension funds, it is fitting now to examine sectors where this evolution has already taken place. In the next section we take a quick look at Brazilian banking regulation regarding credit risks.

\section{THE REGULATION OF CREDIT RISKS IN THE BRAZILIAN BANKING SECTOR}

In 1988, the Basel Committee on Banking Supervision approved the Basel Capital Accord (BCA). This proposal brought a set of guidelines for calculating the minimum capital of banks, which have been adopted by many countries since then.

The focus of the BCA was credit risk, considered the most relevant for the banking system. The BCA associated "risk factors" (Caouette, Altman and Narayanan (2000), Duarte and Varga (2003)) to exposure on and off the balance sheet, according to a broad range of relative risk categories.

In Brazil the initial reflection of the BCA was the issuance of CMN Resolution 2099/94, which covered the minimum capital and net equity adjusted to the level of risk of the asset operations of financial institutions and other establishments authorized to function by the Brazilian Central Bank (BACEN). Later, CMN Resolutions 2390/97 and 2682/99 improved on and gave continuity to the process begun by Resolution 2099/94. In the face of new market pressures, and particularly prompted by the financial scandals of recent years, the New Basel Capital Accord (NBCA, CSBB (2004)) was reached, also known as Basel II.

The NBCA was created to provide bases to allow banks and banking supervisors to more accurately evaluate the various risks (market, credit and operational) faced by financial institutions.

The NBCA is based on three pillars: a minimum capital requirement (Pillar I), the supervisory review process (Pillar II), and market discipline (Pillar III).

Pillar I establishes innovations regarding risks that were not considered in the BCA for the calculation of minimum capital. In this context, operational risk is now considered explicitly.

The proposal for a new regulatory structure maintains both the current definition of the $\mathrm{BCA}$ and the minimum requirement of $8 \%$ of risk-weighted assets. Regarding measurement of credit risk, two forms were introduced to calculate it: the standardized method and the method based on internal models (basic and advanced).

The standardized model is similar to that already in place in Brazil, in that banks must designate their exposures to credit risk mainly in response to the characteristics of the issuers of the assets they hold. In this case, the weightings are based on the use of external risk evaluations by risk rating agencies.

It can be verified that risk weighting through rating agencies allows approximation of the capital requirements to the risk profile chosen by a particular bank (Crouhy, Galai and Mark (2004)). The final numerical value assigned to the credit risk is the sum of the amounts of each asset position multiplied by the risk weighting of that asset, according to its credit risk classification.

Besides classification by type of borrower, according to Table 4, the NBCA also maintains capital requirements based on the risk assumed with some instruments, as described in Table 5, and explained in detail in CSBB (2004). 
Table 4 - Risk Weighting Based on the Standard Model

(following the method of Standard \& Poor's)

\begin{tabular}{l|c|c|c|c|c|c}
\hline & $\mathbf{0 \%}$ & $\mathbf{2 0} \%$ & $\mathbf{5 0 \%}$ & $\mathbf{1 0 0} \%$ & $\mathbf{1 5 0} \%$ & Unrated \\
\hline Sovereign debt & $\mathrm{AAA} / \mathrm{AA}-$ & $\mathrm{A}+/ \mathrm{A}-$ & $\begin{array}{c}\mathrm{BBB}+/ \\
\mathrm{BBB}-\end{array}$ & $\mathrm{BB}+/ \mathrm{BB}-$ & Below B & $100 \%$ \\
\hline Banks & $\mathrm{AAA} / \mathrm{AA}-$ & $\mathrm{A}+/ \mathrm{A}-$ & $\begin{array}{c}\mathrm{BBB}+/ \\
\mathrm{BBB}-\end{array}$ & $\mathrm{BB}+/ \mathrm{BB}-$ & Below B & $100 \%$ \\
\hline$<3$ months & & $\begin{array}{c}\mathrm{AAA} / \\
\mathrm{BBB}-\end{array}$ & $\mathrm{BB}+/ \mathrm{B}-$ & & Below B- & $20 \%$ \\
\hline$>3$ months & & $\mathrm{AAA} / \mathrm{AA}-$ & $\mathrm{A}+/ \mathrm{BBB}-$ & $\mathrm{BB}+/ \mathrm{B}-$ & Below B- & $50 \%$ \\
\hline Corporations & & $\mathrm{AAA} / \mathrm{AA}-$ & $\mathrm{A}+/ \mathrm{BBB}-$ & $\mathrm{BB}+/ \mathrm{B}-$ & Below B- & $100 \%$ \\
\hline Securitizations & & $\mathrm{AAA} / \mathrm{AA}-$ & $\mathrm{A}+/ \mathrm{A}-$ & $\begin{array}{c}\mathrm{BBB}+/ \\
\mathrm{BBB}-\end{array}$ & $\begin{array}{c}\text { Below } \\
\text { BBB- }\end{array}$ & $150 \%$
\end{tabular}

In calculating the minimum capital requirements that must be maintained by banks in function of the exposure of their portfolios to credit risk, the standard method recognizes a wide array of instruments that minimize exposure, among which are guarantees and credit derivatives.

The use of internal models is divided into two versions, basic and advanced. The method used by institutions that opt for one of these versions must be approved by the national supervisor. It enables the bank to utilize its own risk evaluation estimates as an instrument to calculate its capital requirement.

The fact is that the treatment banking supervisors give to the credit risk in financial institutions is concentrated in the asset operations of these institutions. Because of the many financial crises that have occurred in recent decades, these processes are being constantly improved, and have been sufficiently tested in practice.

Table 5 - Risk Weighting of Some Instruments

Retail Portfolio Instruments (personal loans, credit $\quad 75 \%$ card receivables, etc.)

Residential Mortgages

Commercial Mortgages

Non-Performing Loans ( $>90$ days)

$100 \%$

$100 \%$ to $150 \%$

In the Brazilian private pension plan market, as seen previously, the situation is quite different. CMN Resolution 3121/03 imposes numerous restrictions on portfolio allocations according to instruments and/or classes of assets, in an attempt to mitigate risks. But the legislation does not meet its goals, and also winds up generating direct impacts on the concession of benefits and the contributions made by the participants and sponsors of pension funds.

As a reflection of the evolution of the regulatory framework for banks in Brazil, below we set out a proposal for the credit risk evaluation of pension funds that is based on the standard method (for credit risk) of Pillar I of the NBCA.

\section{A PROPOSAL FOR PENSION FUND REGULATION}

The first step that should be taken is the proper regulation of the credit risk rating service. Minimum standards must be established for credit rating agencies to operate in the Brazilian financial market, in line with Castro $(2000,2004)$ and IOSCO (2004), with their ratings/classifications accepted by the regulatory authorities. 
In the process of monitoring the credit rating agencies it is important for there to be interaction with the competent authorities (CVM, BACEN, SUSEP, SPC ${ }^{6}{ }^{\text {etc. }}$ ) in formulating and refining the rules for Brazil. For example, one cannot forget that the NBCA considers the presence of supervisory authorities important in stipulating the criteria that must be met by rating agencies (CSBB (2004)).

Among the minimum standards for a credit rating agency to operate in Brazil, we consider the following:

a) The agency should have a minimum structure compatible with the service being offered. Particular attention should go its technical staff, who need to be duly qualified to undertake the necessary analyses. Preferably all the agency's analysts should have professional certificates (like those described in SERASA (2006), PRMIA (2006) and GARP (2006)).

b) The agency should be required to adopt, implement and ratify procedures and methods, in writing, to ensure that its classifications are based on a complete and transparent analysis of all the relevant information available.

c) The agency should be required to report to the public the analysis of any securities issue that is being traded by the market.

d) The analysis of an issuer should be available to all the market participants that have securities of that issuer.

e) The agency may not have economic or financial exposure that can represent a conflict of interest with the credit analysis activity.

f) Any rupture of the credit rating service agreement should be publicly disclosed, containing the date of cancellation of the contract, date of last analysis, and reason for the termination.

g) The agency should undertake to follow the Code of Conduct available at IOSCO (2004) in its entirety.

Once the minimum standards listed above are satisfied by the risk rating agencies, we can pass to the second phase of this proposal. We take as a basis the standardized methodology of the NBCA, for three reasons:

a) It incorporates exposure to credit risks more precisely than simple limitations on investments in classes of assets and/or financial instruments.

b) It is easy to implement from a computational standpoint, and has already been tested and accepted in practice by the Brazilian financial market.

c) It facilitates standardization in the supervision of credit operations among banks and pension funds (and almost surely insurance companies in the near future, in line with Duarte and Lélis (2004), and Mello and Duarte (2004)).

As an analogy to the standard model of the NBCA (Basel II), a credit risk exposure model can be adopted that consists of making a relation between the asset positions of pension funds and the resources guaranteeing technical reserves (RGTR), as described below:

$$
\frac{\text { Credit Risk }}{\text { RGTR }}=\text { Credit Risk Exposure Index }
$$

where the RGTR are the assets of the investment program additional to cash and cash equivalents, less the amounts payable classified in the operating liabilities of the referred program. The calculation of the credit risk can be described as the summation of

\footnotetext{
${ }^{6} \mathrm{CVM}$ is the Brazilian Securities Commission; BACEN is the Brazilian Central Bank; SUSEP is the Superintendent Office of Private Insurance; SPC is the Secretariat of Complementary Social Security. BBR, Braz. Bus. Rev. (Engl. ed., Online), 
Credit Risk $=\sum$ Positions in Assets $\times$ Weighting of the Assets

The regulatory bodies must establish a maximum level for the credit risk exposure index (CREI) as a way to ensure the solidity and security of the pension fund's portfolio regarding credit risk. This value should be established in consultation with the market.

A possible weighting scheme for the asset positions of pension fund portfolios (similar to the current national banking regulation) is:

a) Give weight zero to bonds issued by the National Treasury, Central Bank, credits securitized by the National Treasury and bonds issued by the states and municipalities that have been refinanced by the National Treasury.

b) Corporate bonds and securitizations can be classified as in Table 6. Corporate bonds are all bonds subject to credit risk of the same company (including financial institutions). Securitization operations include RIFs working with "consigned credit"7 receivables, real estate receivables certificates and agribusiness receivables certificates, among others in this segment.

c) Other state and municipal bonds can also follow Table 6 .

d) Analogously to that stipulated by the NBCA, the weight assigned to personal loans can be $75 \%$, except when the loan is nonperforming. In this case, the part that is not guaranteed can be weighted at $150 \%$. Real estate loans can be weighted at $35 \%$.

e) A weight of $150 \%$ (reflecting higher credit risks) can be assigned to positions such as: (1) bonds issued by special purpose companies to finance projects; and (2) bonds (fixed income) issued by closely held companies, cooperatives and others.

Table 6. Summary of Risk Weightings by Category

\begin{tabular}{l|c|c|c|c|c|c}
\hline & AAA & AA & A & BBB & BB & $\begin{array}{c}\text { Below } \\
\text { BB }\end{array}$ \\
\hline $\begin{array}{l}\text { Corporate Bonds, Securitizations, } \\
\text { State and Municipal Bonds }\end{array}$ & $20 \%$ & $35 \%$ & $50 \%$ & $75 \%$ & $100 \%$ & $150 \%$ \\
\hline
\end{tabular}

Just as in the NBCA, risk mitigating measures should be considered in calculating the risk weighting. For instance, various pension funds stipulate parameters that substantially diminish the credit risk exposure of certain positions, Three examples are:

a) The maximum installment of a personal loan may not exceed a predetermined percentage of the participant's salary (for example, 20\%).

b) People taking out personal loans must contract life insurance to settle the loan balance in case of death.

c) If the borrower decides to stop participating in the pension fund, or the employment relationship ends with the sponsor, the loan will automatically be settled with that individual's savings reserve.

The measures taken in the loan segment to mitigate risk can be considered in the risk calculation, reducing the weight assigned to these loans. For example, if a participant takes out a housing loan, the use of the three mitigating actions above could reduce the weighting by half (that is, from the $35 \%$ mentioned before to $17.5 \%$ ). Other more sophisticated forms can be chosen, according to CSBB (2004).

\footnotetext{
7 "Consigned credit" is a loan type with repayment through automatic deduction from the borrower's paycheck or pension benefits.
} 


\subsection{NUMERICAL EXAMPLE}

To illustrate the practical use o four proposal, we carried out an empirical study consisting of analyzing the investments of six (of the most important) Brazilian pension funds at the end of December 2005. We used the document called the Analytic Statements of Investments and Classification of Investments of the six funds, along with some management reports.

We should point out that it is not the purpose of this numerical example to make comparisons among the management characteristics of these funds, or to make individual evaluations. We only aim to illustrate the form of calculating the proposal presented in practice. Thus, we refer to the funds only as Pension Fund A, Pension Fund B, etc.

Because of the peculiarities of some of the information necessary for the desired calculation, the verification of the use of some credit risk mitigation instruments, mainly for the loan portfolios, required a certain degree of subjectivity on our part. We took a "conservative stance" in calculating the CREI, meaning that in some situations we disregarded some benefits of mitigation measures.

Table 7 shows the composition of the investments, divided into four asset classes. As can be seen, fixed-income investments represent approximately $79.2 \%$ of the total of the six funds, with only Pension Fund $\mathrm{C}$ and Pension Fund $\mathrm{F}$ investing less than $70 \%$ in fixed-income instruments.

\begin{tabular}{l|c|c|c|c}
\multicolumn{5}{c}{ Table 7. Portfolio Composition by Class of Asset } \\
& Fixed Income & $\begin{array}{c}\text { Variable } \\
\text { Income }\end{array}$ & Loans & Real Estate \\
\hline Pension Fund A & $81.3 \%$ & $18.2 \%$ & $0.5 \%$ & $0.0 \%$ \\
\hline Pension Fund B & $94.4 \%$ & $0.0 \%$ & $1.3 \%$ & $4.3 \%$ \\
\hline Pension Fund C & $68.1 \%$ & $25.3 \%$ & $4.4 \%$ & $2.2 \%$ \\
\hline Pension Fund D & $81.8 \%$ & $15.6 \%$ & $2.6 \%$ & $0.0 \%$ \\
\hline Pension Fund E & $100.0 \%$ & $0.0 \%$ & $0.0 \%$ & $0.0 \%$ \\
\hline Pension Fund F & $49.1 \%$ & $35.5 \%$ & $1.2 \%$ & $14.2 \%$ \\
\hline \multicolumn{1}{c|}{ Average } & $\mathbf{7 9 . 2 \%}$ & $\mathbf{1 5 . 8 \%}$ & $\mathbf{1 . 7 \%}$ & $\mathbf{3 . 4 \%}$ \\
\hline
\end{tabular}

Table 8 details the Fixed Income column (of Table 7) into:

a) Federal government bonds; and

b) Bonds issued by private companies.

The table shows that the six funds had a much greater average allocation in public than in private bonds.

Table 9 shows the breakdown for the private bonds into:

a) "Investment grade" fixed-income bonds; and

b) "Speculative grade" fixed-income bonds.

It can be seen that for the pension funds with exposure to private bonds, there is concentration in bonds rated as investment grade by rating agencies, with speculative grade instruments receiving little emphasis.

The calculations to obtain the CREI are shown in the Appendix, using Pension Funds A and $\mathrm{D}$ as examples.

Table 10 presents the CREI calculated using our proposal for each of the six pension funds chosen. This table synthesizes in a single indicator the comparative risk exposure of each of the six funds. Pension Fund F has the highest credit risk exposure according to our 
proposed method. This is in line with Table 8, which shows that this fund has a higher percentage of private bonds in its portfolio than the other funds.

Table 8. Bond Composition of the Portfolios of Six Pension Funds

\begin{tabular}{c|c|c}
\hline & Public Bonds & Private Bonds \\
\hline Pension Fund A & $74.9 \%$ & $6.4 \%$ \\
\hline Pension Fund B & $65.2 \%$ & $29.2 \%$ \\
\hline Pension Fund C & $62.9 \%$ & $5.2 \%$ \\
\hline Pension Fund D & $71.5 \%$ & $10.3 \%$ \\
\hline Pension Fund E & $83.1 \%$ & $16.9 \%$ \\
\hline Pension Fund F & $31.9 \%$ & $17.2 \%$ \\
\hline Average & $\mathbf{6 4 . 9 \%}$ & $\mathbf{1 4 . 2 \%}$ \\
\hline
\end{tabular}

Table 9. Composition of Private Bonds Held by Six Pension Funds

\begin{tabular}{c|c|c}
\hline & Investment Grade & Speculative Grade \\
\hline Pension Fund A & $5.4 \%$ & $1.0 \%$ \\
\hline Pension Fund B & $29.2 \%$ & $0.0 \%$ \\
\hline Pension Fund C & $3.7 \%$ & $1.5 \%$ \\
\hline Pension Fund D & $10.0 \%$ & $0.4 \%$ \\
\hline Pension Fund E & $16.9 \%$ & $0.0 \%$ \\
\hline Pension Fund F & $8.5 \%$ & $8.7 \%$ \\
\hline Average & $\mathbf{1 2 . 3 \%}$ & $\mathbf{1 . 9 \%}$ \\
\hline
\end{tabular}

Table 10. Credit Risk Exposure Index

\begin{tabular}{c|c}
\hline & CREI \\
\hline Pension Fund A & $3.91 \%$ \\
\hline Pension Fund B & $9.70 \%$ \\
\hline Pension Fund C & $7.69 \%$ \\
\hline Pension Fund D & $5.06 \%$ \\
\hline Pension Fund E & $9.44 \%$ \\
\hline Pension Fund F & $17.81 \%$ \\
\hline Average & $\mathbf{8 . 9 4 \%}$ \\
\hline
\end{tabular}

\section{CONCLUSION}

Pension funds are important both for their social objectives and as repositories of longterm internal savings. Consequently, the question arises of the best way to regulate the investments they make with the money under their care.

We found that the Brazilian regulatory framework, although it has been significantly modified in the past decade, has not lost its highly restrictive nature. The problem becomes more serious to the extent that legislation tries to mitigate the credit risk exposure of pension funds by creating different types of restrictions according to financial instruments and/or classes of assets. The reason is that this is not sufficiently effective in practice, causes lower yields, makes management of assets and liabilities more difficult and creates distortions in relation to market rates.

In counterpart, for over a decade the regulation of credit risk in the banking sector has been evolving substantially. This evolution has been the fruit of the greater maturity of the 
sector after facing crises, the advance of technology, the growing volume of (better-examined) data and the research done by specialists in the industry and academe.

Because of these factors, we formulated a proposal for regulating the credit risk of pension funds, using the standardized method of the New Basel Capital Accord (NBCA, or Basel II) as a basis.

Although some modifications can be made in the weightings and risk mitigating factors, the framework of the methodology presented here can improve the management of pension fund resources and substantially facilitate the work of external auditing and supervision.

Future work can use internal models (as in the NBCA) to calculate pension funds' credit risk. Internal models can be more realistic than the standard method in differentiating and capturing more clearly and precisely the credit risks present in financial operations. However, the use of internal models is still in the initial stage in Brazilian banks, and will also demand a significant cultural change by those in charge of managing pension fund portfolios, so we do not see this as a viable alternative in the short run.

\section{REFERENCES}

ABRAPP. Associação Brasileira das Entidades Fechadas de Previdência Privada. Consolidado Estatístico de Junho de 2006. Available at: www.abrapp.org.br. Acesso em setembro de 2006.

Blake, D. "Pension funds and capital markets". Discussion Paper. The Pensions Institute, London, 1997.

Blake D. "Two decades of pension reform in the UK: What are the implications for occupational pension schemes?". Discussion Paper. The Pensions Institute, London, 2000.

Caouette, J.B.; Altman, E.I.; Narayanan, P. Gestão de Riscos de Crédito: O Próximo Grande Desafio Financiero. Editora Qualitymark, Rio de Janeiro, 2000.

Castro, P.R. "O Brasil e as Agências de Rating no Acordo da Basel.” Technical Report, SR Rating, Rio de Janeiro, 2000. Available at: www.srrating.com.br.

Castro, P.R. "Regulação das Agências de Ratings." Technical Report, SR Rating, Rio de Janeiro, 2004. Available at: www.srrating.com.br.

Chutcuti, J.P. "EU Pension Regulation: Liberalisation of Pension Investment". INTERLAWYER Law Firms Directories. Available at www.inter-lawyer.com. Acesso em junho de 2006.

Choi, J.J.; Laibson, D.; Madrian, B.C.; Metrick, A. "Defined Contribution Pensions: Plan Rules, Participant Decisions, and Path of Least Resistance." Discussion Paper. The Pensions Institute, London, 2001.

Conselho Monetário Nacional. - CMN Resolution 2099. Brasília, August 1994.

Conselho Monetário Nacional. - CMN Resolution 2324. Brasília, October 1996.

Conselho Monetário Nacional. - CMN Resolution 2390. Brasília, May 1997.

Conselho Monetário Nacional. - CMN Resolution 2682. Brasília, December 1999.

Conselho Monetário Nacional. - CMN Resolution 2829. Brasília, March 2001.

Conselho Monetário Nacional. - CMN Resolution 3121. Brasília, September 2003.

Conselho Monetário Nacional. - CMN Resolution 3357. Brasília, March 2006. 
Contador, C.R.; Costa, M.RT. "Os Efeitos da Regulamentação nos Investidores Institucionais". Série Relatórios Silcon, Report no. 35, Silcon Estudos Econômicos, Rio de Janeiro, 1998.

Costa e Silva, Eder C. (Consultor sênior da Watson Wyatt) O Caso Aerus,- Caderno A Opinião - Pág 3 - Terça, 25 de Julho de 2006.

Crouhy, M.; Galai, D.; Mark, R. Gerenciamento de Risco: Abordagem Conceitual e Prática. Editora Qualitymark, Rio de Janeiro, 2004.

Csbb. Comitê para Supervisão Bancária da Basel. "Convergência Internacional de Mensuração de Capital e Padrões de Capital". Structure revised with translation by Ernst \& Young. Basel, 2004.

Davis, E.P. (2001) "Portfolio Regulation of Life Insurance Companies and Pension Funds". Discussion Paper PI-0101, The Pensions Institute, London, 2001.

Duarte Jr., A.M.; G. Varga. (organizers) Gestão de Riscos no Brasil. Editora Financial Consultoria, Rio de Janeiro, 2003.

Duarte Jr., A.M.; Lélis, R.J.F. "Unificando a Alocação de Capital em Banco e Seguradoras no Brasil". Revista de Administração de Empresas, 44, 73-84, 2004.

Duarte Jr., A.M. Gestão de Riscos para Fundos de Investimento. Editora Pearson, São Paulo, 2005.

Elton, E.J.; Gruber, M.J.; Brown, S.J.; Goetzmann, W.N. Moderna Teoria das Carteiras e Análise de Investimentos. Editora Atlas, São Paulo, 2004.

Garcia, V.S. "Gerenciamento de riscos em instituições financeiras e o Novo Acordo de Capital”. In: Duarte Jr., A.M.; Varga G. (organizers), Gestão de riscos no Brasil, Editora Financial Consultoria, Rio de Janeiro, 2003.

Garp. Financial Risk Manager. Available at: www.garp.com. Accessed in June 2006

Iosco. International Organization of Securities Commissions. "Code of Conduct Fundamentals for Credit Rating Agencies”. Technical Report, IOSCO. Madrid, 2004.

Mello, L.M.; Duarte Jr., A.M.; "Gestão de Risco de Crédito no Mercado Segurador Brasileiro." Revista Tecnologia de Crédito SERASA, 41, 8-31, 2004.

OECD "OECD Recommendation on Core Principles of Occupational Pension Regulation". Discussion Paper. Organization for Economic Co-operation and Development. Available at: www.oecd.org. Accessed in June 2006a.

OECD "Survey of Investment Regulation of Pension Funds." Discussion Paper. Organization for Economic Co-operation and Development. Available at: www.oecd.org. Accesse in June 2006b.

PREVI. Caixa de Previdência dos Funcionários do Banco do Brasil. Demonstrativo de Investimentos de Junho de 2006. Available at: www.previ.com.br. Accessed in December 2006

PRMIA. Professional Risk Manager's International Association. Available at: www.prmia.org. Accessed in June 2006.

SERASA. Available at: www.serasa.com.br. Accessed in June 2006.

Ziemba, W.T., Mulvey, J.M. (organizers) Worldwide Asset and Liability Modeling. Cambridge University Press, Cambridge, 1998. 


\section{APPENDIX}

We describe here the calculations for measuring the credit risk exposure index (CREI) of two (among the six) Brazilian pension funds considered in the numerical example. To do this, we use formulas (1) and (2).

Tables A1 and A2 summarize the calculations of the two pension funds considered. They also show the facility of this calculation, as long as the assets are already duly identified and classified.

These two examples show that Pension Fund D, despite making loans to participants, has a low credit risk weighting for this specific item when compared to Fund A. This results from the strategy followed by the former entity to mitigate credit risk in the loan segment:

a) Loans are repaid through payroll deductions.

b) Loan amount is limited to the participant's reserve of savings.

c) Obtaining the loan requires the borrower to take out life insurance to cover the loan amount over the life of the loan, in favor of the lender.

These mitigating mechanisms are not present in the case of Fund A.

Table A1. Calculation of the CREI of Pension Fund A

\begin{tabular}{|c|c|c|c|c|}
\hline Assets & Rating & Volume & Weighting & Credit Risk \\
\hline Federal Government Bonds & ------- & $275,882.78$ & $0.00 \%$ & ------- \\
\hline Corporate Bonds & Aaa & $3,229.30$ & $20.00 \%$ & 645.86 \\
\hline Corporate Bonds & $\mathrm{Aa}$ & $10,809.52$ & $35.00 \%$ & $3,783.33$ \\
\hline Corporate Bonds & A & $5,691.26$ & $50.00 \%$ & $2,845.63$ \\
\hline Corporate Bonds & Baa & 278.09 & $75.00 \%$ & 208.57 \\
\hline Corporate Bonds & Unrated & $3,654.94$ & $150.00 \%$ & $5,482.41$ \\
\hline Loans & ------ & $1,933.63$ & $75.00 \%$ & $1,450.22$ \\
\hline Total & & & & $14,416.02$ \\
\hline CREI & & & & $3.91 \%$ \\
\hline
\end{tabular}


Table A2. Calculation of the CREI of Pension Fund D

\begin{tabular}{|c|c|c|c|c|}
\hline Assets & Rating & Volume & Weighting & Credit Risk \\
\hline Federal Government Bonds & ------ & $1,065.75$ & $0.00 \%$ & --------- \\
\hline Corporate Bonds & Aaа & 4.47 & $20.00 \%$ & 0.89 \\
\hline Corporate Bonds & $\mathrm{Aa}$ & 134.51 & $35.00 \%$ & 47.08 \\
\hline Corporate Bonds & $\mathrm{A}$ & 5.37 & $50.00 \%$ & 2.68 \\
\hline Corporate Bonds & $\mathrm{Baa}$ & 5.07 & $75.00 \%$ & 3.80 \\
\hline Corporate Bonds & $\mathrm{Ba}$ & 2.54 & $100.00 \%$ & 2.54 \\
\hline Corporate Bonds & Unrated & 2.68 & $150.00 \%$ & 4.03 \\
\hline Loans & --------- & 38.73 & $37.5 \%$ & 14.52 \\
\hline Total & & & & 75.54 \\
\hline CREI & & & & $5.06 \%$ \\
\hline
\end{tabular}

